\title{
First evaluation of resistance to both a California OsHV-1 variant and a French OsHV-1 microvariant in Pacific oysters
}

\author{
Konstantin Divilov ${ }^{1 *}$ (D), Blaine Schoolfield ${ }^{1}$, Benjamin Morga ${ }^{2}$, Lionel Dégremont ${ }^{2}$, Colleen A. Burge ${ }^{3}$, \\ Daniel Mancilla Cortez ${ }^{4}$, Carolyn S. Friedman ${ }^{5}$, Gary B. Fleener ${ }^{4}$, Brett R. Dumbauld ${ }^{6}$ and Chris Langdon ${ }^{1}$
}

\begin{abstract}
Background: Variants of the Ostreid herpesvirus 1 (OsHV-1) cause high losses of Pacific oysters globally, including in Tomales Bay, California, USA. A suite of new variants, the OsHV-1 microvariants ( $\mu$ vars), cause very high mortalities of Pacific oysters in major oyster-growing regions outside of the United States. There are currently no known Pacific oysters in the United States that are resistant to OsHV-1 as resistance has yet to be evaluated in these oysters. As part of an effort to begin genetic selection for resistance to OsHV-1, 71 families from the Molluscan Broodstock Program, a US West Coast Pacific oyster breeding program, were screened for survival after exposure to OsHV-1 in Tomales Bay. They were also tested in a quarantine laboratory in France where they were exposed to a French OsHV-1 microvariant using a plate assay, with survival recorded from three to seven days post-infection.

Results: Significant heritability for survival were found for all time points in the plate assay and in the survival phenotype from a single mortality count in Tomales Bay. Genetic correlations between survival against the French OsHV-1 $\mu$ var in the plate assay and the Tomales Bay variant in the field trait were weak or non-significant.

Conclusions: Future breeding efforts will seek to validate the potential of genetic improvement for survival to OsHV-1 through selection using the Molluscan Broodstock Program oysters. The lack of a strong correlation in survival between OsHV-1 variants under this study's exposure conditions may require independent selection pressure for survival to each variant in order to make simultaneous genetic gains in resistance.
\end{abstract}

Keywords: Ostreid herpesvirus 1, Crassostrea gigas, Heritability, Breeding

\section{Background}

Ostreid herpesvirus 1 (OsHV-1) is a widely distributed virus found to be the cause of Pacific oyster (Crassostrea gigas) mortality in oyster-growing countries of Europe, Australia, New Zealand, and the United States [1-5]. In Europe, Australia, and New Zealand, the OsHV-1 microvariants ( $\mu$ vars), which are distinguished from other variants by DNA sequence variations at two loci in the viral genome [6], are the most commonly found variants. OsHV-1 $\mu$ vars were originally detected in France and are thought to cause greater mortality than other variants [5]; however, to our knowledge, an experiment

\footnotetext{
* Correspondence: divilovk@oregonstate.edu

'Department of Fisheries and Wildlife, Coastal Oregon Marine Experiment Station, Oregon State University, Hatfield Marine Science Center, Newport, Oregon, USA

Full list of author information is available at the end of the article
}

quantifying the difference in survival of genetically similar oysters challenged by $\mu$ vars and non- $\mu$ vars under the same environmental conditions has yet to be performed in the laboratory. In the United States, OsHV-1 has been detected in adjacent northern California bays, primarily Tomales Bay [1, 7] and also Drakes Bay [8] and Bodega Bay (Burge, Moore, and Marshman unpub.).

Breeding for genetic resistance to OsHV-1 $\mu$ vars in Pacific oysters has been successful in France and Australia. In France, four generations of mass selection starting from wild naturalized Pacific oysters resulted in an increase in OsHV-1 $\mu$ var survival in the field from 7 to $69 \%$ on average for three- to six-month-old selected oysters [9]. Mass selection consists of returning surviving oysters to the hatchery for spawning to create the next generation. This presents a considerable risk to hatchery 
operations if the hatchery is in a virus-free location, which is the case for hatcheries in the United States. In Australia, three generations of family-based selection starting from oysters previously selected for growth resulted in an increase in OsHV-1 survival in the field from 10 to $40 \%$ for one-year-old oysters for all families in the breeding program and from 40 to $85 \%$ for the top five families [10].

Laboratory screening methods for resistance to OsHV$1 \mu$ vars have been evaluated as an alternative to field screenings. Correlations between OsHV-1 $\mu$ var survival of oysters planted in three field locations in France and aquarium-held oysters injected intramuscularly with a purified virus ranged from 0.68 to 0.74 [11]. Similarly, genetic covariances ranging from 0.77 to 1.05 were found between field exposure to OsHV-1 and laboratory cohabitation with injected oysters in France [12]. Correlations between OsHV-1 survival of oysters planted over a period of three years in one field location in Australia and aquarium-held oysters exposed to OsHV-1 $\mu$ var ranged from 0.41 to 0.91 [10]. Further, correlations between OsHV-1 survival of oysters planted in two locations in New Zealand and aquarium-held oysters exposed to either a high or low concentration of OsHV$1 \mu \mathrm{var}$ ranged from 0.40 to 0.70 [13]. These results suggest that it is possible to use OsHV-1 $\mu$ var survival of oysters tested using laboratory assays as a proxy for OsHV-1 $\mu$ var survival in the field.

No oysters bred for OsHV-1 resistance to any variant are available in the United States. The rapid spread of the virus, as seen by the emergence of $\mu$ vars in Europe in 2008 [5] and Australia and New Zealand in 2010 [2, 3], presents a significant risk to the US West Coast Pacific oyster industry. Restrictions on international and interstate oyster transportation currently exist in the US, but hypothesized modes of transmission other than oyster movement, such as ballast water and biofouling [14], limit the ability of these restrictions to prevent the spread of the Tomales Bay variant or $\mu$ vars from other countries. Breeding oysters for resistance to OsHV-1 variants requires that the resistance be heritable, or under genetic control, in a breeding population.

Our objective in this study was to determine if the current oyster population at the Molluscan Broodstock Program (MBP), a United States West Coast Pacific oyster breeding program, has heritable variation in resistance to both the Tomales Bay variant (C-89) and a French $\mu$ var (C-25) of OsHV-1. As multiple OsHV-1 genotypes may be present in a particular location, the variant names will be accompanied by their " $\mathrm{C}$ " region genotypes as specified by Mineur et al. [15]. MBP has selected oyster families for improved yield since 1996 [16, 17]. There have only been two plantings of MBP families in Tomales Bay for the purpose of selection in October 1996 and 1999 [17]; therefore, a substantial level of resistance to mortality due to OsHV-1 in the breeding population was not expected.

\section{Methods \\ Pacific oyster families}

Seventy-five biparental oyster families were produced in February 2018 in the MBP hatchery at the Hatfield Marine Science Center (Newport, OR) according to previously reported methods [16, 17]. All oysters in a biparental oyster family are full siblings that were derived from one female and one male oyster. Seventy-one MBP families were selected on the basis of parental performance for yield, one family was a hybrid produced from two oysters inbred for three generations, two families had parents that naturally set in Willapa Bay, and one family was created for the purpose of commercial use by West Coast hatcheries.

Three French biparental oyster families and two French multiparental oyster families were produced in March 2018 at the Ifremer hatchery (La Tremblade, Marennes-Oléron Bay, France) according to previously reported methods [9]. Two biparental families were selected for resistance to OsHV-1 $\mu$ vars, while one biparental family was selected for susceptibility to the virus. The two remaining families were unselected for their survival to OsHV-1 $\mu$ vars and each was produced through a mass spawn of 30 oysters. The five oyster families were kept in a quarantine facility at the Ifremer station using UV-treated $\left(40 \mathrm{~mJ} / \mathrm{cm}^{2}\right)$ seawater to prevent infection by OsHV-1 $\mu$ vars, which are present in the adjacent Marennes-Oléron Bay.

\section{Plate assay under quarantine conditions in France}

Two hundred and fifty, three-month-old randomly selected oyster spat from 69 MBP families and the hybrid family were placed in mesh bags and shipped on ice to the Ifremer Laboratory of Genetics and Pathology of Marine Molluscs (La Tremblade, France) on 21 May 2018. An authorization was obtained from the Directorate-General for Food of the French Ministry of Agriculture and Food prior to exporting the oysters from the United States. Spat arrived without mortality on 24 May 2018 and were placed in an aerated $120 \mathrm{~L}$ circulating aquarium at $20^{\circ} \mathrm{C}$ with UV-treated and $50 \mu \mathrm{m}$ sand-filtered seawater, addition of $17 \mu$ lof the antibiotic Flumisol ${ }^{\circ} 36 \% / \mathrm{L}$, and no addition of microalgae. Flumisol ${ }^{\circ}$ was used to prevent bacterial blooms. After $24 \mathrm{~h}$ in the aquarium, spat from each of the 69 MBP families, one hybrid family, and the five French families were placed in three six-well plates held in a room at $20^{\circ} \mathrm{C}$. Each well held five spat that ranged from 5 to $10 \mathrm{~mm}$. For each family, two plates were used for the viral exposure treatment while the third served as a control. The viral exposure treatment involved adding $10 \mathrm{ml}$ of OsHV-1 $\mu$ var-contaminated seawater to 
each well, while the control treatment involved adding UV-treated and filtered seawater to each well.

OsHV-1 $\mu$ var-contaminated seawater was prepared by placing thirty-five 11-month-old naïve oysters in a $20 \mathrm{~L}$ aerated aquarium with $17 \mu \mathrm{l}$ Flumisol 36\%/L and $50 \mathrm{~g} / \mathrm{L}$ $\mathrm{MgCl}_{2}$ for two hours. Magnesium chloride $\left(\mathrm{MgCl}_{2}\right)$ was used to induce gaping of oysters and facilitate injection of the virus suspension into their adductor muscles [18]. Each oyster was injected with $100 \mu \mathrm{l}$ of 1000 DNA copies of OsHV-1 $\mu \mathrm{var} / \mu \mathrm{l}$ and returned to the aquarium with new seawater. The OsHV-1 $\mu$ var originated from tissue samples collected in 2016 from ten moribund oysters in the Marennes-Oléron Bay (France). The following day, oysters were removed from the aquarium, which held the contaminated seawater with a concentration of $2.2 \times 10^{7}$ OsHV $-1 \mu$ var copies $/ \mathrm{ml}$. To determine the concentration, total DNA was extracted from the seawater using the QIAamp DNA Mini Kit (QIAgen) following the manufacturer's protocol, and DNA quality and quantity were determined with a NanoDrop 2000 (Thermo Scientific). OsHV-1 $\mu$ var DNA was quantified by qPCR in duplicate using an Mx3000 Thermocycler (Agilent) following a protocol developed by Pepin et al [19]. Amplification reactions were performed in a total volume of $20 \mu \mathrm{l}$. Each well contained $5 \mu \mathrm{l}$ of genomic DNA $(5 \mathrm{ng} / \mathrm{mL}), 10 \mu \mathrm{l}$ of Brillant III Ultra-Fast SYBR Green Master Mix (Agilent), $2 \mu \mathrm{l}$ of each primer $(5.5 \mu \mathrm{M}$ : OsHV-1 DPFor 5' -ATTGATGATGTGGATAATCTGTG3', $5.5 \mu \mathrm{M}$ OsHV-1 DPRev 5'-GGTAAATACCATTG GTCTTGTTCC-3') [20], and $1 \mu \mathrm{l}$ of distilled water. qPCR cycling conditions were: $3 \mathrm{~min}$ at $95^{\circ} \mathrm{C}$, followed by 40 cycles of amplification at $95^{\circ} \mathrm{C}$ for $5 \mathrm{~s}$, and $60^{\circ} \mathrm{C}$ for $20 \mathrm{~s}$.

Daily spat mortality counts were performed between three and seven days post-infection for the viral exposure and control treatments, with dead spat discarded after being counted. Spat were considered dead if they were gaping and did not close their shells upon physical agitation.

An additional three groups of spat were treated as the viral exposure treatment above for the purpose of viral DNA quantification over time. One group consisted of five families, which were randomly sampled among the MBP families, while the other two groups contained the French selected resistant and susceptible families. Spat from a well were sampled and pooled daily starting from the day of inoculation until the end of the experiment. DNA extraction and OsHV-1 $\mu$ var DNA quantification was performed as above with three replicates per group per day.

\section{Field trial in Tomales Bay, California}

Four replicates of three-month-old randomly selected oyster spat, 5 to $10 \mathrm{~mm}$ in size, from 70 biparental families were planted in the outer bay of Tomales Bay (California,
USA) on 23 May 2018 in a completely randomized design using the rack and bag method of oyster culture. The planted families included 64 out of the 69 MBP families tested in the plate assay, two additional MBP families, one hybrid family, two naturalized Willapa families, and one commercial family. A large $13 \mathrm{~mm}$ mesh grow-out bag $(0.6 \times 0.9 \mathrm{~m})$ was used to hold four separate small $3 \mathrm{~mm}$ mesh replicate bags $(0.3 \times 0.3 \mathrm{~m})$. Each small mesh bag held 35 oysters from a single family. The large bags were arranged in four rows and 20 columns at the same intertidal height. $\mathrm{A} \mathrm{HOBO}^{\mathrm{mm}}$ temperature logger was placed in one of the large bags at planting. Oysters were checked biweekly for significant mortality. Due to resource limitations, all MBP families could not be planted in the field trial, and spat mortality counts, as well as DNA sampling for qPCR, were performed only once at the first observed significant mortality event, which was recorded on $1 \mathrm{Au}$ gust 2018.

OsHV-1-specific qPCR was used to determine the viral load in 31 live and 23 dead MBP oysters selected randomly in the field. The Zymo Quick-DNA Mini Plus kit was used following the manufacturer's protocol to extract $\sim 25 \mathrm{mg}$ of gill and mantle tissue from each oyster. Using methods of Burge and Friedman [21] with some modifications, we targeted the OsHV-1 ORF 100/catalytic subunit of a DNA polymerase $\delta$ using the following forward (5'TGATGGATTGTTGGACGAGA-3') and reverse (5'ATCACATCCCTGGACGCTAC-3') primers and a standard curve from 3 to $3 \times 10^{7}$ copies per reaction. Briefly, each $20 \mu \mathrm{l}$ reaction included $10 \mu \mathrm{l}$ of the Fast SYBR $^{\circ}$ Green Master Mix, $15 \mu \mathrm{g}$ of BSA, $300 \mathrm{nM}$ of each primer, and $2 \mu \mathrm{l}$ of DNA. All standard curves were run in triplicate and samples in duplicate. All qPCR reactions were done using the Applied Biosystems 7500 Fast Realtime PCR system with a cut-off of 3 copies per reaction. Cycling conditions for each qPCR run were: $95^{\circ} \mathrm{C}$ for $20 \mathrm{~s}$ followed by 40 cycles of $95^{\circ} \mathrm{C}(3 \mathrm{~s})$ and $60^{\circ} \mathrm{C}(30 \mathrm{~s})$. Following each run, a melting curve analysis was performed to confirm the specificity of each qPCR reaction by comparing the melting temperature peak of the positive control DNA to that of the experimental samples. Additionally, to confirm amplifiable DNA in all samples, we targeted the Pacific oyster $18 \mathrm{~S}$ gene using the primers CG $18 \mathrm{~S}$ F 5'-CAGCGAAAGCATTTGCCAAG-3' and CG $18 S$ R 5' CACCCA CCG AAT CAA GAA AGA G 3' [21]. Reaction conditions were the same as above; however, cycling conditions were: $95^{\circ} \mathrm{C}$ for $20 \mathrm{~s}$ followed by 40 cycles of $95^{\circ} \mathrm{C}$ for $3 \mathrm{~s}$ and $55^{\circ} \mathrm{C}$ for $30 \mathrm{~s}$. A melting curve analysis was performed after each run as above.

\section{Statistical methodology}

Genetic selection for disease resistance is successful only when genetic variation exists for a resistance phenotype, which was cumulative percent survival for each plate 
containing a single family in the plate assay and percent survival for each small bag containing a single family in the field trial. A Bayesian Gaussian process regression model [22] was used to estimate the genetic and error variances in order to estimate heritability and its uncertainty. A high heritability means that closely related families are more similar in their survival than distantly related families. The 71 MBP families are the seventh selected MBP generation and are all genetically related through a pedigree [16].

The assumptions for the model were:

$$
\mathbf{y} \sim \mathrm{N}\left(\boldsymbol{\mu}, \sigma_{\mathrm{a}}^{2} \mathbf{A}+\sigma_{\mathrm{e}}^{2} \mathbf{I}\right) \sigma_{\mathrm{a}}^{2}, \sigma_{\mathrm{e}}^{2} \sim \mathrm{U}\left(0, \sigma_{\mathrm{y}}^{2}\right)
$$

The phenotype $\mathbf{y}$ was assumed to be distributed as a multivariate normal distribution with the mean $\boldsymbol{\mu}$ being the mean of $\mathbf{y}$ and the covariance matrix $\sigma_{\mathrm{a}}^{2} \mathbf{A}+\sigma_{\mathrm{e}}^{2} \mathbf{I}$, where $\mathbf{A}$ was the additive relationship matrix [23], $\sigma_{a}^{2}$ was the additive genetic variance, I was an identity matrix, and $\sigma_{\mathrm{e}}^{2}$ was the error variance. The additive relationship matrix was created using the relatedness of the current generation of oysters with the preceding six generations. The variances were assumed to be distributed as uniform distributions bound between zero and the variance of $\mathbf{y}$. The posterior distributions of the variances were obtained through Markov chain Monte Carlo (MCMC) sampling using the No-U-Turn sampler implemented in Stan [24]. Four Markov chains were generated with 10,000 iterations per chain, half of which were warmup iterations. Convergence of the Markov chains to the posterior variance distributions was checked by observing if the Gelman-Rubin statistic was close to one [25]. The 20,000 post-warmup samples were used to obtain posterior modes and $95 \%$ highest posterior density intervals [22] for the variance and heritability estimates. Heritability $\left(h^{2}\right)$ was calculated as $\frac{\sigma_{a}^{2}}{\sigma_{a}^{2}+\frac{\sigma_{e}^{2}}{n}}$ where $n$ was the number of replicates, which was two in the plate assay and four in the field trial. A parameter was considered significant if its $95 \%$ highest posterior density interval did not include zero.

To determine if survival values to the French OsHV-1 $\mu$ var $(\mathrm{C}-25)$ and the Tomales Bay (C-89) OsHV-1 variant were correlated, 95\% confidence intervals for Pearson correlation coefficients between breeding values of phenotypes were calculated to determine significant correlations, which were correlations whose confidence intervals did not contain zero, from the Fisher transformation [26]. Breeding values of phenotypes were obtained from the equation $\boldsymbol{\mu}+\sigma_{\mathrm{a}}^{2} \mathbf{A}\left(\sigma_{\mathrm{a}}^{2} \mathbf{A}+\sigma_{\mathrm{e}}^{2} \mathbf{I}\right)^{-\mathbf{1}}(\mathbf{y}-\boldsymbol{\mu})$, Because not all 71 MBP families were tested in both experiments, breeding values of families missing in either experiment were predicted by adding their relationships to the non-missing families as rows in the left-hand side A of the above equation.

\section{Results \\ Plate assay}

Only a single oyster in the control treatment died among all MBP, hybrid, and French families tested. The distribution for the mean cumulative survival in the viral exposure treatment on day three was truncated normal and on days four to seven were approximately normal, with mean cumulative survival decreasing over time (Fig. 1a). By day seven, the two French selected resistant families had a higher cumulative survival (100 and 95\%) than the two French unselected families (45 and 30\%) and the French selected susceptible family (21\%). The hybrid family had a cumulative survival $(5 \%)$ that was greater than four MBP families out of the 69 MBP families tested. The mean cumulative survival of the MBP families was 34\% and varied greatly from 0 to $84 \%$. The mean absolute difference in percent survival among replicates of the MBP families was $6,10,14,18$, and $17 \%$, respectively, for days three to seven. No viral DNA was detected in spat from the MBP or French families at the beginning of the plate assay. Viral DNA concentrations increased over the span of the experiment in the five random MBP and French selected susceptible families with the French selected resistant families having significantly lower viral DNA than MBP families by day seven (Fig. 2a). The mean cumulative survival of the five random MBP families was the same as that of all the MBP families (34\%). The cumulative survival phenotypes for each time point were significantly heritable, with the highest heritability at five days post-infection (0.69) and the lowest heritability at three days postinfection (0.57) (Table 1). The breeding values between any two time points were significantly positively correlated (0.59-0.95) (Table 2).

\section{Field trial}

On 1 August 2018, family mortality counts from a significant mortality event coinciding with elevated temperatures (Fig. 3) were recorded and showed a truncated normal distribution (Fig. 1b). The two naturalized Willapa families (97 and 92\%) and the commercial family (93\%) had higher survival than the hybrid family (71\%), which had greater survival than 14 MBP families out of the 66 MBP families tested. The survival phenotype among the MBP families had a mean of $83 \%$ and ranged from 45 to $99 \%$ and the phenotype was significantly heritable (Table 1). The mean standard deviation among replicates was $18 \%$. All sampled oysters except five live oysters tested positive for OsHV-1 DNA, and all sampled oysters except one dead oyster had amplifiable DNA. Viral DNA concentrations from live oysters sampled were uniformly distributed in the logarithm scale 

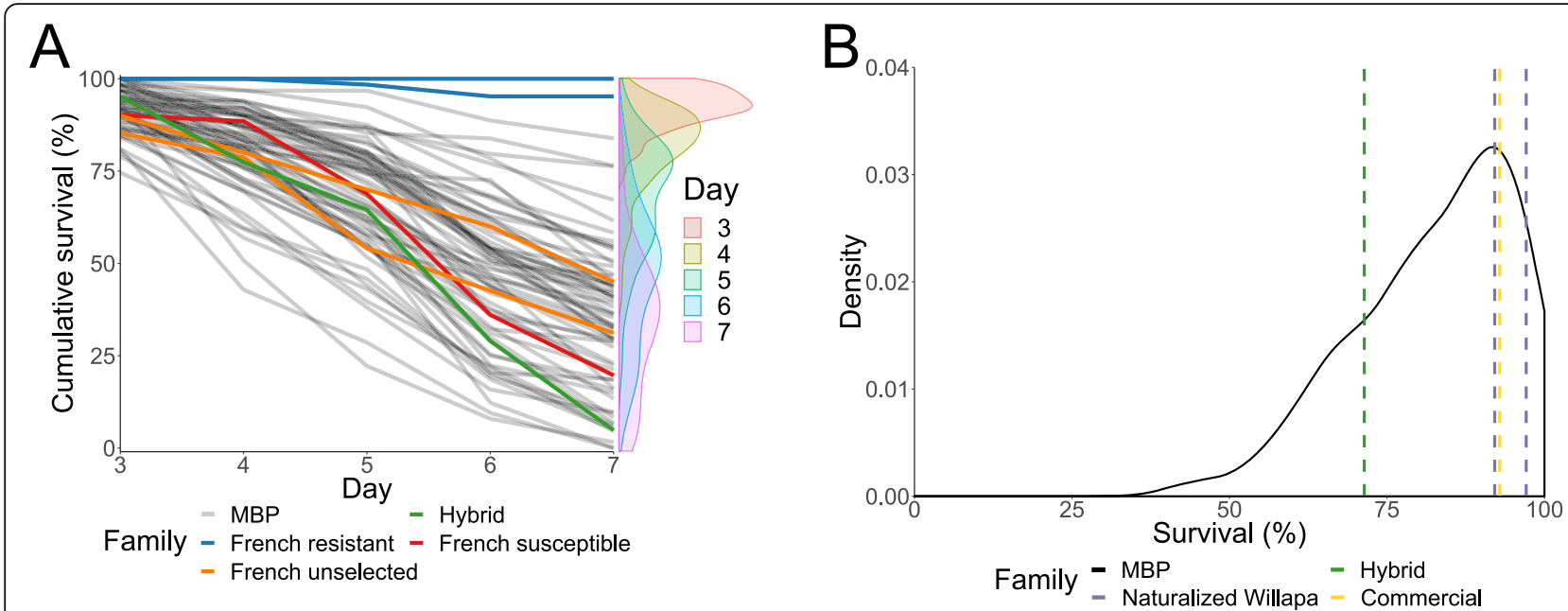

Fig. 1 a Mean cumulative percent survival of 69 MBP families, one hybrid family, two French selected resistant families, one French selected susceptible family, and two French unselected families from day three post-infection with the French OsHV-1 variant (C-25) to day seven in a plate assay in France with two replications. Distributions of the mean cumulative percent survival are shown on the right-hand side. $\mathbf{b}$ Distribution of the mean percent survival of 66 MBP families replicated four times after a significant OsHV-1 (C-89) mortality event in Tomales Bay, California with the mean percent survival of one hybrid family, two naturalized Willapa families, and one commercial family shown by dashed vertical lines

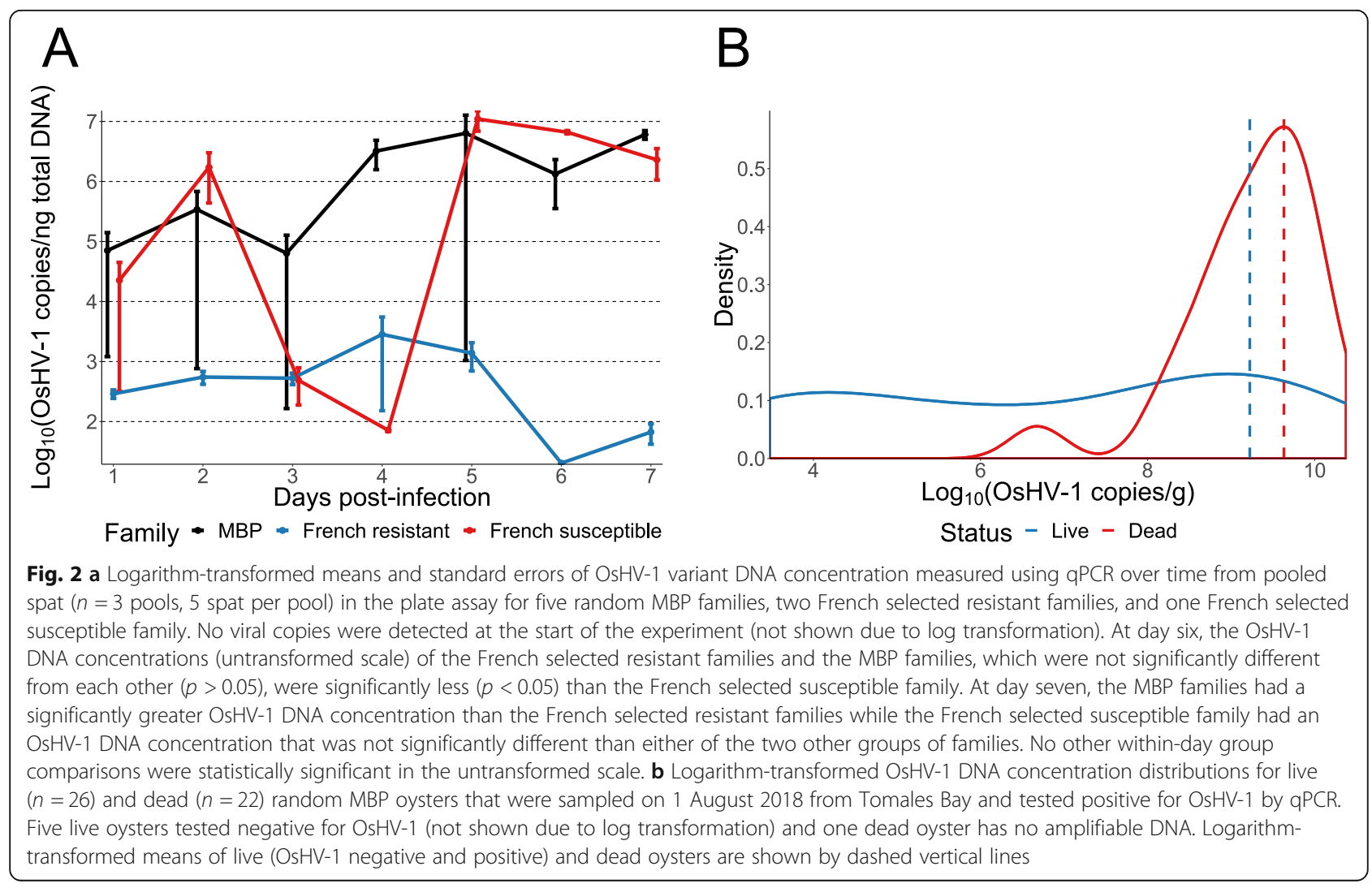


Table 1 Posterior modes (95\% highest posterior density intervals in parentheses) of Bayesian Gaussian process regression model parameters estimated from the MBP families for the plate assay (PA) across days post-infection and the Tomales Bay field trial (TB). The parameters are the genetic $\left(\sigma_{a}^{2}\right)$ and error $\left(\sigma_{\mathrm{e}}^{2}\right)$ variances. Heritability $\left(h^{2}\right)$ is a statistic calculated from the variances

\begin{tabular}{llll}
\hline Phenotype & $\sigma_{a}^{2}$ & $\sigma_{e}^{2}$ & $h^{2}$ \\
\hline PA Day 3 & $15.76(3.42-34.56)$ & $33.13(24.59-45.76)$ & $0.57(0.22-0.74)$ \\
PA Day 4 & $81.61(39.99-141.44)$ & $88.12(65.03-127.46)$ & $0.68(0.46-0.80)$ \\
PA Day 5 & $160.46(82.36-266.01)$ & $162.29(116.53-226.35)$ & $0.69(0.49-0.81)$ \\
PA Day 6 & $225.05(97.14-406.81)$ & $292.37(205.81-409.70)$ & $0.63(0.40-0.79)$ \\
PA Day 7 & $229.34(100.40-415.37)$ & $282.49(205.72-410.45)$ & $0.65(0.41-0.79)$ \\
TB & $79.31(31.41-160.97)$ & $318.01(272.47-388.68)$ & $0.53(0.31-0.70)$ \\
\hline
\end{tabular}

(Fig. 2b) and ranged from zero OsHV-1 copies/g to $2.4 \times 10^{10}$ OsHV-1 copies/g. Viral DNA concentrations from dead oysters sampled were approximately normally distributed in the logarithm scale and ranged from $4.8 \times$ $10^{6}$ OsHV-1 copies/g to $2.2 \times 10^{10}$ OsHV-1 copies/g. The mean viral DNA concentrations for the live and dead oysters were $1.7 \times 10^{9} \mathrm{OsHV}-1$ copies/g and $4.3 \times$ $10^{9} \mathrm{OsHV}-1$ copies/g, respectively.

\section{Correlation between the plate assay and field trial}

A weak but significant correlation of 0.24 was found between the day three plate assay breeding values and the field trial breeding values as well as between the day seven plate assay and the field trial (Table 2; Fig. 4). No other between-experiment correlations were significant.

\section{Discussion}

Significant genetic variation for resistance to two variants of OsHV-1 exists in the MBP breeding population (Table 1), which has not been previously selected for this trait. This finding is similar to the results reported for the French and Australian breeding programs $[9,10]$, where genetic variation for resistance to OsHV-1 was reported in previously unselected Pacific oysters and used to develop resistant broodstock. Whether the molecular pathways responsible for resistance to OsHV-1 are similar in resistant oysters from these breeding programs remains to be determined.

By using time-series viral DNA quantification in the plate assay and individual oyster OsHV-1 quantification from oysters in Tomales Bay, we confirmed that the mortality observed in both experiments was related to the presence of high loads of OsHV-1 DNA (Fig. 2), although other causes might interact in Tomales Bay. Seawater temperature data suggest that the mass mortality event observed was partly due to mean temperatures reaching $18^{\circ} \mathrm{C}$ and above (Fig. 3), which is lower than the constant $20^{\circ} \mathrm{C}$ experienced by spat in the laboratory plate assay. Mortality due to OsHV-1 in the outer bay of Tomales Bay, where the oysters were planted in this study, has previously been reported to be correlated to temperatures above $16^{\circ} \mathrm{C}$ [1]. The French resistant families managed to limit infection by the OsHV-1 $\mu$ var in comparison to the MBP families or the French susceptible family (Fig. 2a), confirming the previously reported resistance in the French-bred resistant families [27-29]. Mean survival among MBP families in the Tomales Bay field trial was high, as was the variance in survival among families (Fig. 1). Consideration of OsHV-1 survival in Tomales Bay during commercial broodstock selection should increase the mean survival of oysters in the resulting families as the survival variance was partly genetic (Table 1). While survival of the MBP families was high in this field trial, it reflects a single mortality event and the single count did not allow for a final mortality count; however, the plate assay results suggest that obtaining multiple mortality counts over time would not greatly alter this estimate of trait heritability. Furthermore, OsHV-1 survival is partly a function of temperature, so a longer elevated temperature event within permissive temperatures would likely cause greater mortality $[1,30,31]$. If strong genetic

Table 2 Pearson correlation coefficients (95\% confidence intervals in parentheses) between breeding values of phenotypes for the plate assay (PA) across days post-infection and the Tomales Bay field trial (TB)

\begin{tabular}{|c|c|c|c|c|c|c|}
\hline & PA Day 3 & PA Day 4 & PA Day 5 & PA Day 6 & PA Day 7 & TB \\
\hline PA Day 3 & 1 & $0.74(0.61-0.83)$ & $0.67(0.51-0.78)$ & $0.66(0.51-0.78)$ & $0.59(0.41-0.72)$ & $0.24(0.01-0.45)$ \\
\hline PA Day 4 & & 1 & $0.93(0.88-0.95)$ & $0.86(0.78-0.91)$ & $0.79(0.69-0.87)$ & $0.2(-0.04-0.41)$ \\
\hline PA Day 5 & & & 1 & $0.90(0.85-0.94)$ & $0.84(0.75-0.90)$ & $0.17(-0.06-0.39)$ \\
\hline PA Day 6 & & & & 1 & $0.95(0.92-0.97)$ & $0.17(-0.06-0.39)$ \\
\hline PA Day 7 & & & & & 1 & $0.24(0.01-0.45)$ \\
\hline TB & & & & & & 1 \\
\hline
\end{tabular}




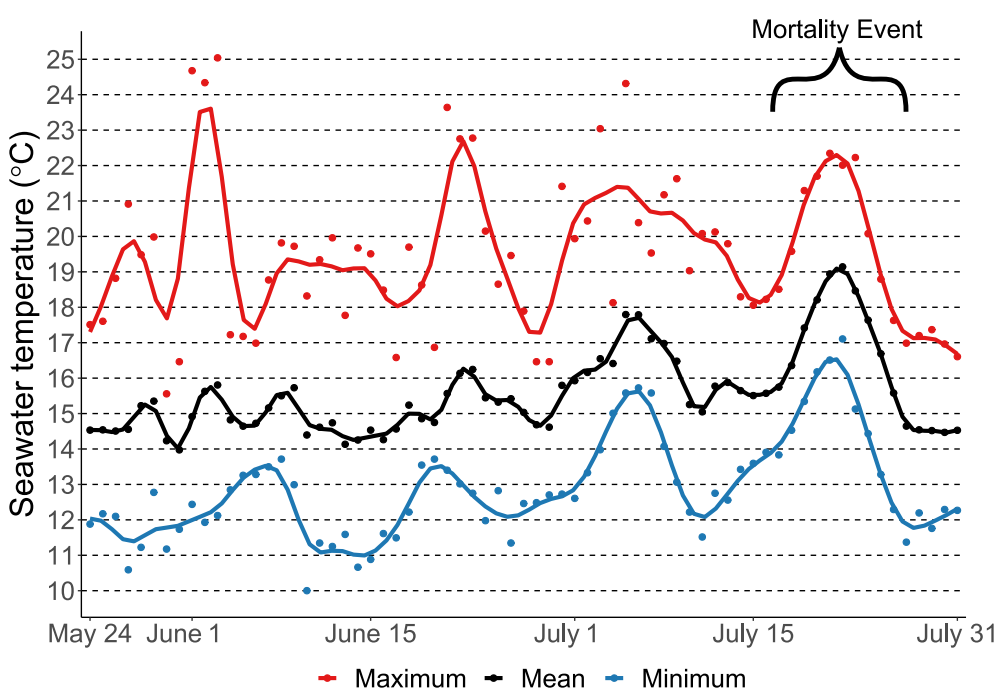

Fig. 3 Maximum, mean, and minimum daily seawater temperatures at the Tomales Bay planting site from the day after planting to the day before phenotyping the oysters for survival against the OsHV-1 mortality event plotted as raw values (points) and smoothed lines. Spat were planted on 23 May 2018 and OsHV-1 survival was phenotyped on 1 August 2018

correlations do not exist between OsHV-1 survival influenced by temperature events of varying severity, field trials would be an ineffective resistance screening method as oyster growers desire OsHV-1 survival to the worst-case scenario. Additionally, other factors possibly influencing OsHV-1 survival, such as Vibrio spp. [27], should be considered in future studies to ensure that selected broodstock are resistant to OsHV-1 across a broad range of environments on the West Coast.

Surprisingly, the genetic correlations between resistance to a French OsHV-1 $\mu$ var $(\mathrm{C}-25)$ and resistance to the Tomales Bay OsHV-1 variant (C-89) were weak or nonsignificant (Table 2). An explanation for this might be that only some pathways are effective against particular OsHV-

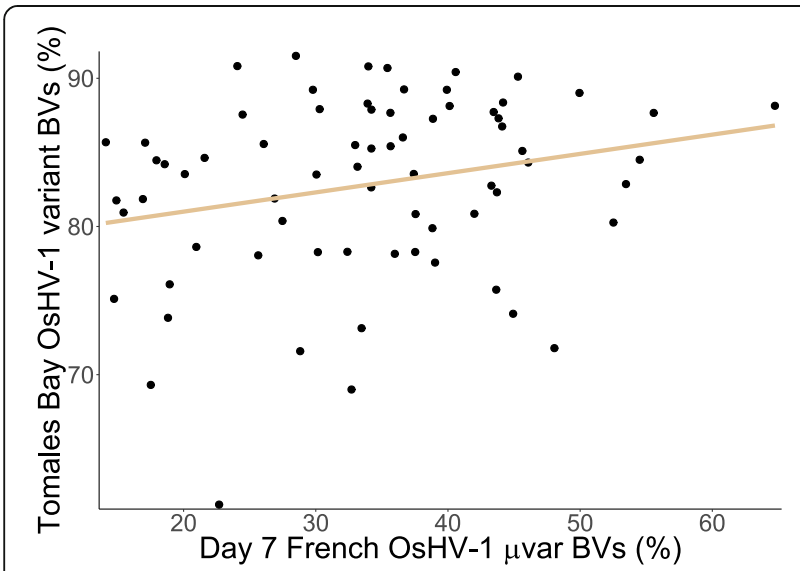

Fig. 4 Breeding values (BVs) of MBP families for survival to the French OsHV-1 $\mu$ var (C-25) in the plate assay seven days postinfection and to the Tomales Bay OsHV-1 variant (C-89) in the field trial with the line of best fit
1 variants due to evolution by the virus. It has been reported that oysters become more resistant to OsHV-1 as they age [32, 33], so an interaction between genotype and age might account for the low correlation as the spat in the plate assay were three months old when exposed to OsHV-1 while the spat in the field trial were five months old when exposed to OsHV-1 in combination with an elevated temperature event. Testing both variants in the laboratory with spat fertilized on the same date would determine if the cross-variant correlation deviates significantly from one. If the correlation does not deviate significantly from one, it would be advantageous to continue to test families at multiple ages to exploit the genotype-byage effect such that oyster families that have high OsHV-1 survival at more than one stage of maturity can be selected. This selection would eliminate the need to plant older oysters on the West Coast to avoid OsHV-1 mortality. Despite the low genetic cross-variant correlations, MBP families with high survival breeding values to both variants exist (Fig. 4) and can be used as parents in future generations.

\section{Conclusions}

This study is the first large-scale screening of Pacific oyster families from the West Coast of the United States for resistance to two variants of OsHV-1. We found that the MBP families have a significant amount of genetic variation in resistance to both the Tomales Bay OsHV-1 variant and the French OsHV-1 $\mu$ var. This variation can be exploited through family-based selection to develop resistant broodstock; however, selection for survival to one variant may not greatly increase survival to the other 
variant due to a low observed correlation between the survival breeding values in the MBP population.

\section{Abbreviations}

MBP: Molluscan Broodstock Program; MCMC: Markov chain Monte Carlo; OsHV-1: Ostreid herpesvirus 1; PA: Plate assay; TB: Tomales Bay; uvar: Microvariant

\section{Acknowledgements}

We thank Marilyn Leary, Lexington Preheim, and Elise Maurouard for their assistance in setting up the experiments; and the Hog Island Oyster Co. for providing the planting site and personnel in Tomales Bay. We thank Michael Banks for reviewing a draft of this manuscript.

\section{Ethical approval and consent to participate}

Crassostrea gigas is not a protected invertebrate.

\section{Authors' contributions}

$\mathrm{KD}, \mathrm{BM}, \mathrm{CAB}, \mathrm{LD}, \mathrm{CSF}, \mathrm{BD}$, and $C L$ conceived and designed the study. $K D, B S$, $B M, C A B, L D, D M C$, and GBF performed the experiments. KD conducted the statistical analysis and wrote the draft manuscript. All authors read, edited, and approved the final manuscript.

\section{Funding}

Funding for this study and $K D$, as well as partial funding for $C A B$ and $C L$, was provided by the USDA-ARS project 2072-31000-004-00D "Genetic Improvement of Oyster Stocks for the Pacific Northwest". The Molluscan Broodstock Program is funded by an appropriation from the Legislature of the State of Oregon.

\section{Availability of data and materials}

The data and code used to run the analyses are available at https://github. com/kdivilov/BMC_Genetics_2019.

\section{Consent for publication}

Not applicable.

\section{Competing interests}

The authors declare that they have no competing interests.

\section{Author details}

${ }^{1}$ Department of Fisheries and Wildlife, Coastal Oregon Marine Experiment Station, Oregon State University, Hatfield Marine Science Center, Newport, Oregon, USA. ${ }^{2}$ Laboratoire de Génétique et Pathologie des Mollusques Marins, Ifremer, La Tremblade, France. ${ }^{3}$ Institute of Marine and Environmental Technology, University of Maryland Baltimore County, Baltimore, Maryland, USA. ${ }^{4}$ Hog Island Oyster Co., Marshall, California, USA. ${ }^{5}$ School of Aquatic and Fishery Sciences, University of Washington, Seattle, Washington, USA. ${ }^{6}$ United States Department of Agriculture-Agricultural Research Service, Hatfield Marine Science Center, Newport, Oregon, USA

Received: 15 April 2019 Accepted: 21 November 2019 Published online: 12 December 2019

\section{References}

1. Burge CA, Griffin FJ, Friedman CS. Mortality and herpesvirus infections of the Pacific oyster Crassostrea gigas in Tomales Bay, California. USA Dis Aquat Org. 2006;72(1):31-43.

2. Jenkins C, Hick P, Gabor M, Spiers Z, Fell SA, Gu X, Read A, Go J, Dove M, O'Connor W, Kirkland PD, Frances J. Identification and characterisation of an ostreid herpesvirus-1 microvariant (OsHV-1 $\mu$-var) in Crassostrea gigas (Pacific oysters) in Australia. Dis Aquat Org. 2013;105(2):109-26.

3. Keeling SE, Brosnahan CL, Williams R, Gias E, Hannah M, Bueno R, McDonald WL, Johnston C. New Zealand juvenile oyster mortality associated with ostreid herpesvirus 1 an opportunistic longitudinal study. Dis Aquat Org 2014;109(3):231-9.

4. Peeler EJ, Reese RA, Cheslett DL, Geoghegan F, Power A, Thrush MA Investigation of mortality in Pacific oysters associated with Ostreid herpesvirus-1 $\mu$ Var in the Republic of Ireland in 2009. Prev Vet Med. 2012; 105(1-2):136-43
5. Segarra A, Pépin JF, Arzul I, Morga B, Faury N, Renault T. Detection and description of a particular Ostreid herpesvirus 1 genotype associated with massive mortality outbreaks of Pacific oysters, Crassostrea gigas, in France in 2008. Virus Res. 2010;153(1):92-9.

6. OIE. Infection with ostreid herpesvirus 1 microvariants. World Organisation for Animal Health. 2018.

7. Friedman CS, Estes RM, Stokes NA, Burge CA, Hargove JS, Barber BJ, Elston RA, Burreson EM, Reece KS. Herpes virus in juvenile Pacific oysters Crassostrea gigas from Tomales Bay, California, coincides with summer mortality episodes. Dis Aquat Org. 2005;63(1):33-41.

8. Burge CA, Strenge RE, Friedman CS. Detection of the oyster herpesvirus in commercial bivalves in northern California, USA: conventional and quantitative PCR. Dis Aquat Org. 2011;94(2):107-16.

9. Dégremont L, Nourry M, Maurouard E. Mass selection for survival and resistance to OsHV-1 infection in Crassostrea gigas spat in field conditions: response to selection after four generations. Aquaculture. 2015;446:111-21.

10. Kube P, Dove M, Cunningham M, Kirkland P, Gu X, Hick P, O'Connor W, Elliot N. Genetic Selection for Resistance to Pacific Oyster Mortality Syndrome. 2018. FRDC and Seafood CRC Project 2012/760.

11. Dégremont L, Lamy JB, Pépin JF, Travers MA, Renault T. New insight for the genetic evaluation of resistance to Ostreid herpesvirus infection, a worldwide disease, in Crassostrea gigas. PLoS One. 2015;10(6):e0127917.

12. Azéma P, Lamy JB, Boudry P, Renault T, Travers MA, Dégremont L. Genetic parameters of resistance to Vibrio aestuarianus, and OsHV-1 infections in the Pacific oyster, Crassostrea gigas, at three different life stages. Genet Sel Evol. 2017;49(1):23.

13. Camara MD, Yen S, Kaspar HF, Kesarcodi-Watson A, King N, Jeffs AG, Tremblay LA. Assessment of heat shock and laboratory virus challenges to selectively breed for ostreid herpesvirus 1 (OsHV-1) resistance in the Pacific oyster, Crassostrea gigas. Aquaculture. 2017;469:50-8.

14. Whittington RJ, Paul-Pont I, Evans O, Hick P, Dhand NK. Counting the dead to determine the source and transmission of the marine herpesvirus OsHV-1 in Crassostrea gigas. Vet Res. 2018;49(1):34.

15. Mineur F, Provan J, Arnott G. Phylogeographical analyses of shellfish viruses: inferring a geographical origin for ostreid herpesviruses OsHV-1 (Malacoherpesviridae). Mar Biol. 2015;162(1):181-92.

16. de Melo CMR, Durland E, Langdon C. Improvements in desirable traits of the Pacific oyster, Crassostrea gigas, as a result of five generations of selection on the west coast, USA. Aquaculture. 2016;460:105-15.

17. Langdon C, Evans F, Jacobson D, Blouin M. Yields of cultured Pacific oysters Crassostrea gigas Thunberg improved after one generation of selection. Aquaculture. 2003;220(1):227-44.

18. Suquet M, de Kermoysan G, Araya RG, Queau I, Lebrun L, Le Souchu P, Mingant C. Anesthesia in Pacific oyster, Crassostrea gigas. Aquat Living Resour. 2009;22(1):29-34

19. Pepin JF, Riou A, Renault T. Rapid and sensitive detection of ostreid herpesvirus 1 in oyster samples by real-time PCR. J Virol Methods. 2008; 149(2):269-76.

20. Webb SC, Fidler A, Renault T. Primers for PCR-based detection of ostreid herpes virus-1 (OsHV-1): application in a survey of New Zealand molluscs. Aquaculture. 2007;272(1-4):126-39.

21. Burge CA, Friedman CS. Quantifying ostreid herpesvirus (OsHV-1) genome copies and expression during transmission. Microb Ecol. 2012;63(3):596-604.

22. Gelman A, Stern HS, Carlin JB, Dunson DB, Vehtari A, Rubin DB. Bayesian Data Analysis. 2013. Chapman and Hall/CRC.

23. Henderson CR. A simple method for computing the inverse of a numerator relationship matrix used in prediction of breeding values. Biometrics. 1976; 32(1):69-83.

24. Carpenter B, Gelman A, Hoffman MD, Lee D, Goodrich B, Betancourt M, Brubaker MA, Guo J, Li P, Riddell A. Stan: A probabilistic programming language. J Stat Softw. 2017;76(1)

25. Gelman A, Rubin DB. Inference from iterative simulation using multiple sequences. Stat Sci. 1992;7(4):457-72

26. Fisher RA. On the probable error of a coefficient of correlation deduced from a small sample. Metron. 1921;1:3-32.

27. de Lorgeril J, Lucasson A, Petton B, Toulza E, Montagnani C, Clerissi C, VidalDupiol J, Chaparro C, Galinier R, Escoubas J-M, Haffner P, Dégremont L, Charrière GM, Lafont M, Delort A, Vergnes A, Chiarello M, Faury N, Rubio T, Leroy MA, Pérignon A, Régler D, Morga B, Alunno-Bruscia M, Boudry P, Le Roux F, Destoumieux-Garzón D, Gueguen Y, Mitta G. Immune-suppression by OsHV-1 viral infection causes fatal bacteraemia in Pacific oysters. Nat Commun. 2018;9:4215 
28. Dégremont L. Evidence of herpesvirus (OsHV-1) resistance in juvenile Crassostrea gigas selected for high resistance to the summer mortality phenomenon. Aquaculture. 2011;317(1-4):94-8.

29. Segarra A, Mauduit F, Faury N, Trancart S, Dégremont L, Tourbiez D, Haffner P, Barbosa-Solomieu V, Pépin J-F, Travers M-A, Renault T. Dual transcriptomics of virus-host interactions: comparing two Pacific oyster families presenting contrasted susceptibility to ostreid herpesvirus 1. BMC Genomics. 2014;15:580

30. Delisle L, Petton B, Burguin JF, Morga B, Corporeau C, Pernet F. Temperature modulate disease susceptibility of the Pacific oyster Crassostrea gigas and virulence of the Ostreid herpesvirus type 1. Fish Shellfish Immunol. 2018;80:71-9.

31. Petton B, Pernet F, Robert R, Boudry P. Temperature influence on pathogen transmission and subsequent mortalities in juvenile Pacific oysters Crassostrea gigas. Aquac Environ Interact. 2013;3(3):257-73.

32. Dégremont L. Size and genotype affect resistance to mortality caused by OsHV-1 in Crassostrea gigas. Aquaculture. 2013;416-417:129-134.

33. Petton B, Boudry P, Alunno-Bruscia M, Pernet F. Factors influencing diseaseinduced mortality of Pacific oysters Crassostrea gigas. Aquac Environ Interact. 2015;6(3):205-22.

\section{Publisher's Note}

Springer Nature remains neutral with regard to jurisdictional claims in published maps and institutional affiliations.

Ready to submit your research? Choose BMC and benefit from:

- fast, convenient online submission

- thorough peer review by experienced researchers in your field

- rapid publication on acceptance

- support for research data, including large and complex data types

- gold Open Access which fosters wider collaboration and increased citations

- maximum visibility for your research: over $100 \mathrm{M}$ website views per year

At BMC, research is always in progress.

Learn more biomedcentral.com/submissions 